\title{
Evaluation of Toxicity of a Textile Dye (Optilan Red) towards a Green Microalga Chlorella vulgaris
}

\author{
Samchetshabam Gita ${ }^{1}$, S.P. Shukla ${ }^{1}$, Chandra Prakash ${ }^{2}$, Neelam Saharan ${ }^{1}$ and \\ Geetanjali Deshmukhe ${ }^{3}$ \\ ${ }^{1}$ Aquatic Environment and Health Management Division, ${ }^{2}$ Aquaculture Division, \\ ${ }^{3}$ FRPHM division, ICAR-Central Institute of Fisheries Education, Mumbai, \\ Maharashtra, India - 400061 \\ *Corresponding author
}

\section{A B S T R A C T}

In this study, the effect of textile dye (Optilan Red) toward microalgae Chlorella vulgaris

\section{Keywords}

Optilan red, SGR, EC50, Protein, Pigment, Chlorella vulgaris

Article Info

Accepted:

20 July 2018

Available Online:

10 August 2018 was monitored for a period of 96 hours. The parameters such as specific growth rate

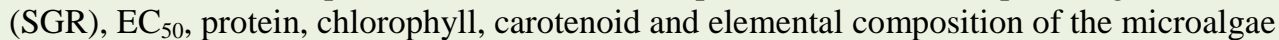
were recorded. Results showed that SGR for $C$. vulgaris decreased with increase in concentration of dye and a significant decrease was noticed upto $20 \mathrm{ppm}$ however, further increase in concentration showed no growth of the organism. $\mathrm{EC}_{50}$ for Optilan Red was found to be $23.16 \mathrm{ppm}$. The protein level of treated $C$. vulgaris showed significant reduction in all the concentrations. Further significant increase in percentage protein inhibition was noticed with increase in dye concentrations. More than $50 \%$ reduction in level of both pigments evident at $50 \mathrm{ppm}$. Maximum percentage inhibition was $66.6 \%$ and $79.4 \%$ for total chlorophyll and carotenoid, respectively (at $50 \mathrm{ppm}$ ). It was noticed that elemental composition of $C$. vulgaris was reduced significantly as compared to the control. This study emphasizes that assessment of toxicity of textile dyes towards photoautotrophic organisms including micro-algae is of prime importance to assess the impacts of dye pollution in aquatic environment.

\section{Introduction}

Dyes may be defined as substances providing color to the substrate (Kirk-Othmer, 2004; Bafana et al., 2011; Drumond Chequer et al., 2013). Such substances with considerable colouring capacity are widely employed in the textile, pharmaceutical, food, cosmetics, plastics, photographic and paper industries
(Bafana et al., 2011; Rocha et al., 2016). In the textile industry, up to 200,000 tons of these dyes are lost to effluents every year during the dyeing and finishing operations, due to the inefficiency of the dyeing process (Ogugbue and Sawidis, 2011). In addition, the increased demand for textile products and the proportional increase in their production, and the use of synthetic dyes have together 
contributed to dye wastewater becoming one of the substantial sources of severe pollution problems in current times (Ogugbue and Sawidis, 2011; Dos et al., 2007). Unfortunately, most of these dyes escape from textile industry persist in the environment as a result of their high stability to light, temperature, water, detergents, chemicals, soap and other parameters such as bleach and perspiration (Couto, 2009). The wastewater from textile plants is classified as the most polluting of all the industrial sectors, considering the volume generated as well as the effluent composition (Sen and Demirer, 2003; Ben et al., 2012). Textile wastewaters are characterized by extreme fluctuations in many parameters such as chemical oxygen demand, biochemical oxygen demand, $\mathrm{pH}$, color and salinity. This wastewater contains mixture of natural and synthetic dye including azo, methane, nitro, and carbonyl that recalcitrant to the degradation (Syafalni et al., 2012). These discharges of synthetic dye into the aquatic system have generated much concern due to its reported genotoxic, mutagenic, teratogenic and carcinogenic effects (Srivastava et al., 2004; Chowdhury and Saha, 2010). In addition, the effects caused by other pollutants in textile wastewater, and the presence of very small amounts of dyes ( $<1 \mathrm{mg} / \mathrm{L}$ for some dyes) in the water, which are nevertheless highly visible, seriously affects the aesthetic quality and transparency of water bodies such as lakes, rivers and others, leading to damage to the aquatic environment (Ibrahim et al., 1996; Wijetunga et al., 2010; Gita et al., 2017a).

Microalgae are microscopic unicellular organisms capable of converting solar energy to chemical energy via photosynthesis. However, there is much utilization of microalgae in aquaculture which mainly related to nutrition, the basis of the energy flow through the aquatic grazing food chain (De and Persoon, 1988). But due to discharge of synthetic dye in aquatic environment from the textile factories found toxic to various aquatic microorganism. In general, dyes have low toxicity in mammals and aquatic organisms (O'Neill et al., 1999), but products formed by their biodegradation, mainly aromatic amines from the anaerobic reduction of dyes, can be harmful (Razo et al., 1997; Pinheiro et al., 2004). It hinders growth, pigment content, protein content and also disturb the photosynthetic activity. Some dyes are highly toxic and mutagenic that it decreases light penetration and causing oxygen deficiency and limiting downstream beneficial uses such as recreation, drinking water and irrigation (Forgacs et al., 2004; Przystaś et al., 2012; Hubbe et al., 2012). During the recent past year few studies has been carried out and reported on effect of various dyes in microalgae.

In earlier study on the toxicity of textile dye (Metomega Chrome Orange GL) towards a diazotrophic cyanobacteruim Nostoc muscorum found that protein, chlorophyll-a, phytocyanin and carotenoid content showed a progressive decreased with concentration of the dye and decreased in photosynthetic evolution also observed by 75,81 , and $92 \%$ (Shukla et al., 1992). Another study on toxicity assessment was performed using Selenastrum capricornutum chronic toxicity test at $1 \mathrm{mg} / \mathrm{L}$ of the active colorant in the dyes. All except two of the dyes examined have anionic colorants and many of which are reactive and metal complexes. Only the two cationic dyes demonstrated toxicity (Greene et al., 1996). In 2005, a studied on comparative use of bacterial, algal and protozoan tests to study toxicity of azo- and anthraquinone dyes. Among these, $S$. capricornutum algal test was the most sensitive to evaluate toxicity of the dyes (Novotny et al., 2006). Further, most of the toxicity studies were carried out in microalgae were mainly focused on cyanobacteria and other microalgae. Based on 
the above context, evaluation of toxicity of textile dye, Optilan Red towards Chlorella vulgaris has been carried out to examine the toxic effect of dye on C. vulgaris.

\section{Materials and Methods}

\section{Culture of Chlorella vulgaris}

Algal sample was obtained from Micro- Algal laboratory, Aquatic Environmental Management, ICAR-CIFE. The unialgal populations of $C$. vulgaris were cultured under prescribed photoautotrophic conditions (Ripka et al., 1979) in BG-11 (Allen, 1968) selective media and maintained in Micro- Algal laboratory of Aquatic Environmental Management, ICAR-CIFE. The pure culture of $C$. vulgaris was sub-cultured in sterile BG11 medium under photoautotrophic conditions in plant growth chamber with an illumination of $3500 \pm 100$ lux using compact fluorescent lamps (Philips, $23 \mathrm{~W}$ ).

The photoperiod was fixed at 16:8 hour light and dark periods and temperature was maintained at $24 \pm 2^{\circ} \mathrm{C}$. The cultures were shaken twice a day to ensure the proper mixing of the algal suspension. The culture was transferred to $20 \mathrm{~L}$ capacity glass aspirator bottle for the continuous culture of alga. The cultures were aerated using stoneaerator which supplied air at the bottom of the vessel, and the air-flow was adjusted to a level that ensured proper mixing of the culture.

\section{Preparation of textile dyes solution}

Textile dye optilan red was supplied free of cost by Achroma limited (Mumbai, India). From the 50 ppm stock solution, working solutions of $10,20,30,40,50 \mathrm{ppm}$ were prepared by dissolving required quantity of dye powder in deionised water as per (Gita et al., 2017b).

\section{Toxicity testing}

Toxicity experiment was conducted according to OECD guidelines 201 (OECD 1984) with certain modifications when necessary. An inoculum of Chlorella vulgaris was prepared for the experiment in BG-11 medium two days before the test to ensure that the algal cells exposed to dyes are in exponential phase. Exponentially growing algal culture was harvested by centrifugation and re-suspended in the dyes solution of graded concentrations in medium. The culture density for all the experiments was maintained at $3 \times 10^{5}$ cells $\mathrm{mL}^{-1}$.

Three replicates at each test concentration including control were incubated in plant growth chamber for $96 \mathrm{hr}$ under the following photoautotrophic conditions, temperature: 24 $\pm 2{ }^{0} \mathrm{C}$; light intensity: $3500 \pm 100 \mathrm{lux}$ and photoperiod was fixed at 16:8 hour light and dark periods. The cultures were manually shaken twice a day to re-suspend any settled cells. Samples were analysed every $24 \mathrm{hrs}$ time interval by measuring the direct optical density at $650 \mathrm{~nm}$ using a Double beam UVvisible spectrophotometer (MOTRAS Scientific, New Delhi) and calculate the specific growth rate and generation time, protein content and pigment content.

\section{Growth rate or doubling time}

The specific growth rate $(\mathrm{K})$ of the alga was calculated by using the formula given by Kartz and Myers (1955):

$$
\mathrm{K}\left(\mathrm{day}^{-1}\right)=\frac{2.303 \log N_{\mathrm{t}}-\log N_{0}}{T_{\mathrm{t}}-T_{0}} .
$$

where, $\mathrm{N}_{0}$ is the initial optical density at 650 $\mathrm{nm}$ at time $\mathrm{T}_{0}$ and $\mathrm{N}_{\mathrm{t}}$ is the final number optical density at time $T_{t}$ when culture is in exponential phase. 
The generation time or mean generation time (days) was calculated using the formula:

$x=\frac{\ln (2)}{k}=\frac{0.693}{k}$

Where, $\mathrm{K}$ is the specific growth rate

\section{Pigment content}

After $96 \mathrm{hr}$ exposure of algal cells in graded concentration of optilan red dye, a volume of $15 \mathrm{ml}$ algal cells were taken in a $15 \mathrm{ml}$ centrifuged tube and centrifuged (Eltek Microprocessor High-speed Research refrigerated centrifuge, MP $400 \mathrm{R}$, India) at $5000 \mathrm{rpm}$ for $10 \mathrm{~min}$. The supernatant containing the dye was discardedand algal pellets were washed three times with sterilized double-distilled water to remove the dye molecules adsorbed on the surface of cells and $15 \mathrm{~mL}$ of $\mathrm{N}, \mathrm{N}$-dimethylformamide (DMF) was added to the remaining pellets and kept for 24-h for incubation at the room temperature. Then, centrifuged for $10 \mathrm{~min}$ at $5000 \mathrm{rpm}$ and supernatants were collected in centrifuged tube and optical densities were measured at precribed wavelength $(461 \mathrm{~nm}$ and $664 \mathrm{~nm}$ ) and total chlorophyll and carotenoid were estimated.

The pigments Chlorophyll (Moran, 1982) and carotenoid (Chromavitz, 1993) was estimated by the following formula:

Total chlorophyll $=(\mu \mathrm{g} / \mathrm{ml})=$ O.D. ${ }_{664} \times 11.92$

Carotenoid $(\mu \mathrm{g} / \mathrm{ml})=$ [O.D.461 $(0.046 \times$ O.D.664] $\times 4$

\section{Protein content}

For estimation of protein content for $C$. vulgaris $1 \mathrm{~mL}$ volume of sample were taken at 24-h intervals during the test period and protein content was estimated in each sample using bovine serum albumin (BSA) as a standard protein by applying the method given by Lowry method (Lowry, 1951).

\section{Estimation of $\mathrm{EC}_{50}$}

96-h $\mathrm{EC}_{50}$ of Optilan Red dye for C. vulgaris was calculated using probit analysis, SPSS 22.0. $\mathrm{EC}_{50}$ is the concentration of the test substance that results in $50 \%$ reduction in growth or algal cells within the stated exposure period.

\section{CHNS analysis}

After 96-h of exposure, algal cells inoculated in BG-11 medium having concentration of $\mathrm{EC}_{50}$ value of Optilan Red dyes was centrifuged and washed with distilled water to remove the dye completely from the algal cells. Algal sample was oven dried at $60^{\circ} \mathrm{C}$ overnight and prepare into powdered form. The powdered algal samples was analysed using CHNS Analyzer (Elementar, VarioMICRO, India). Then, carbon, nitrogen, hydrogen, and sulfur content were estimated.

\section{Results and Discussion}

\section{Growth curve of Chlorella vulgaris}

Algal growth was measured for every $24 \mathrm{hr}$ for the culture period of 10 days. The specific growth rate and generation time of alga was recorded as 0.295 day $^{-1}$ and 2.35 days, respectively.

\section{Algal growth inhibition test}

The effects of the various concentrations of Optilan Red dyes on the specific growth rate, $\mathrm{EC}_{50}$, protein content and pigment content for C. vulgaris was studied for the exposure period of 96 hours. The concentration range taken for the algal growth inhibition test was determined on the basis of results from rangefinding tests. 


\section{Specific growth rate}

After exposing $C$. vulgaris to the graded concentrations of Optilan Red dye, it was observed that with an increase in the concentration of dye, the specific growth rate (SGR) of C. vulgaris was decreases upto 20 ppm and no growth was detected from 30 ppm. A significant $(\mathrm{p}<0.05)$ decreased in the specific growth rate and increase in the generation time of $C$. vulgaris for all the concentrations of the dye was recorded (Table $1)$.

\section{Percentage growth inhibition}

Based on the optical densities of cells in the controls and treatments, percentage inhibition of SGR was calculated post 96-h of the experiment. A significant difference $(\mathrm{p}<0.05)$ in percentage SGR inhibition of $C$. vulgaris was observed among the various concentrations of OptilanRed dye. The highest percent inhibition for Optilan Red (82\%) was occurred at $20 \mathrm{ppm}$ concentration (Figure 1).
Estimation of median effective concentration $\left(\mathbf{E C}_{50}\right)$ : Post $96-\mathrm{h} \quad \mathrm{EC}_{50}$ of Optilan Red dye for C. vulgariswas found to be 23.16 ppm at $95 \%$ confidence limit.

\section{Protein content inhibition}

The protein content of $C$. vulgaris exposed to various concentrations of Optilan Red dye was measured after 96hrs exposure. The protein level of treated $C$. vulgaris showed significant reduction in all the concentration. Further significant increase in percentage protein inhibition was noticed with increased in dye concentrations (Figure 2).

\section{Pigment content inhibition}

The content and composition of pigments in C. vulgaris were measured after 96-h of exposure to dye. The pigments, chlorophyll and carotenoids were measured and showed significant inhibition with increased in concentration of dye.

Table.1 Effect of various concentrations of Optilan Red (ppm) on SGR and Generation time of C. vulgaris (Data are represented in mean $\pm \mathrm{SE}, \mathrm{n}=3$ )

\begin{tabular}{|l|l|l|}
\hline $\begin{array}{l}\text { Dye (Optilan Red) } \\
\text { Concentration }\end{array}$ & Average SGR $\left(\right.$ day $\left.^{-1}\right)$ & Generation time (days) \\
\hline Control & $0.105 \pm 0.01$ & $6.695 \pm 0.619$ \\
\hline $\mathbf{1 0} \mathbf{~ p p m}$ & $0.038 \pm 0.001$ & $18.197 \pm 0.61$ \\
\hline $\mathbf{2 0} \mathbf{~ p p m}$ & $0.022 \pm 0.000$ & $31.236 \pm 0.000$ \\
\hline $\mathbf{3 0} \mathbf{~ p p m}$ & NGD & NGD \\
\hline $\mathbf{4 0} \mathbf{~ p p m}$ & NGD & NGD \\
\hline $\mathbf{5 0} \mathbf{~ p p m}$ & NGD & NGD \\
\hline
\end{tabular}

[NGD: No growth detected; The data are significant difference $(\mathrm{p}<0.05)$ from each other] 
Table.2 Effect of Optilan Red on major elements composition of C. vulgaris (Data are represented in mean $\pm \mathrm{SE}, \mathrm{n}=3$ )

\begin{tabular}{|l|l|l|}
\hline Elements & Percent content & \\
\cline { 2 - 3 } & Controls & Optilan red \\
\hline Nitrogen & $8.603^{\mathrm{A}} \pm 0.494$ & $8.231^{\mathrm{A}} \pm 0.131$ \\
\hline Carbon & $43.826^{\mathrm{A}} \pm 0.182$ & $43.425^{\mathrm{B}} \pm 0.050$ \\
\hline Hydrogen & $4.987^{\mathrm{A}} \pm 0.145$ & $4.866^{\mathrm{A}} \pm 0.144$ \\
\hline Sulfur & $1.223^{\mathrm{A}} \pm 0.154$ & $0.000^{\mathrm{B}} \pm 0.000$ \\
\hline
\end{tabular}

${ }^{\#} \mathrm{~A}$ and $\mathrm{B}$ denote the significant $(\mathrm{p}<0.05)$ difference in between the treatment and corresponding control tested by independent t-test.

Fig.1 Effect of various concentrations Optilan Red (ppm) on the growth of C. vulgaris. Data are represented in mean $\pm \mathrm{SE}, \mathrm{n}=3$

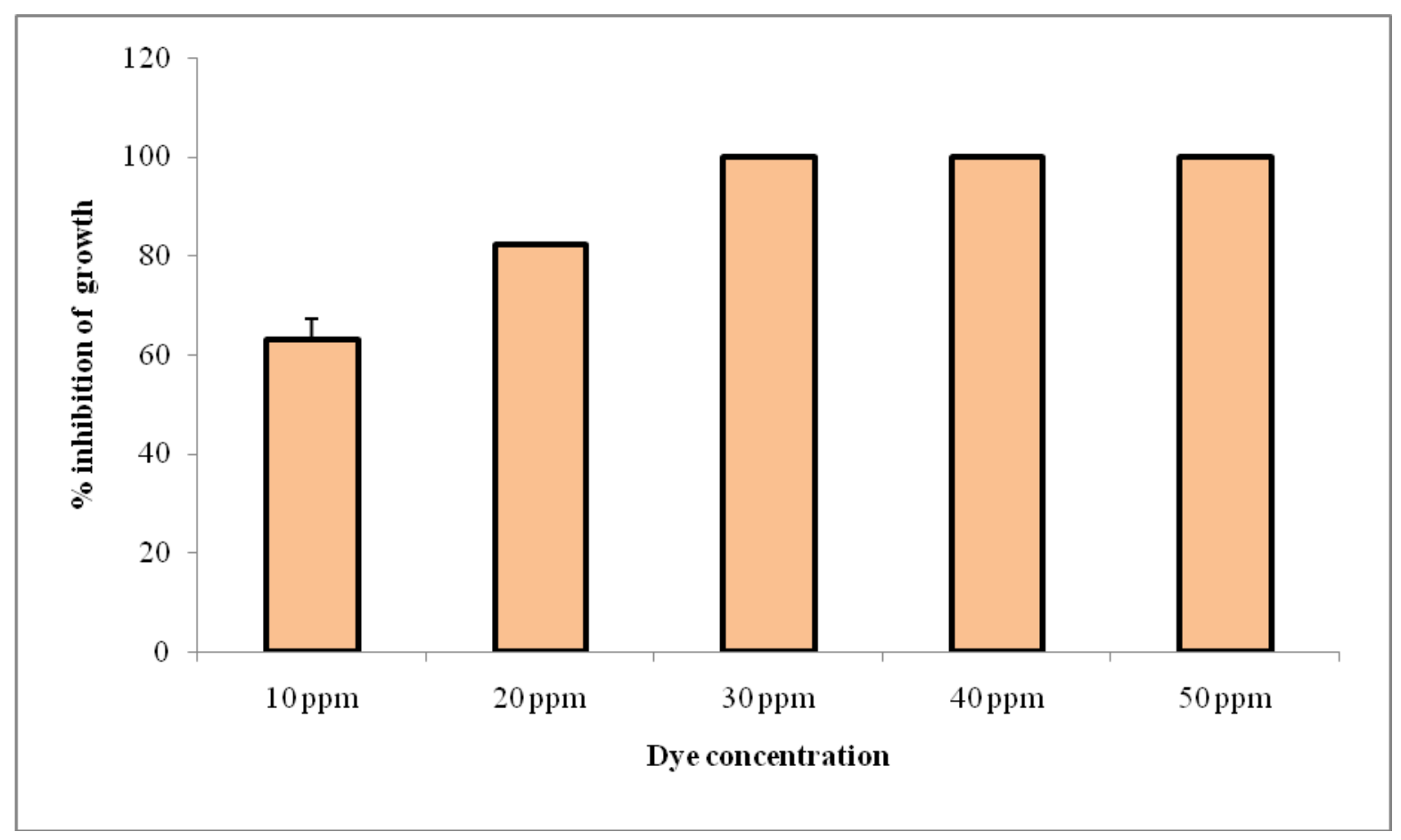


Fig.2 Effect of various concentrations of Optilan Red on the protein content of C. vulgaris after $96 \mathrm{~h}$. Data are represented in mean $\pm \mathrm{SE}, \mathrm{n}=3$. The data are significant difference $(\mathrm{p}<0.05)$ from each other

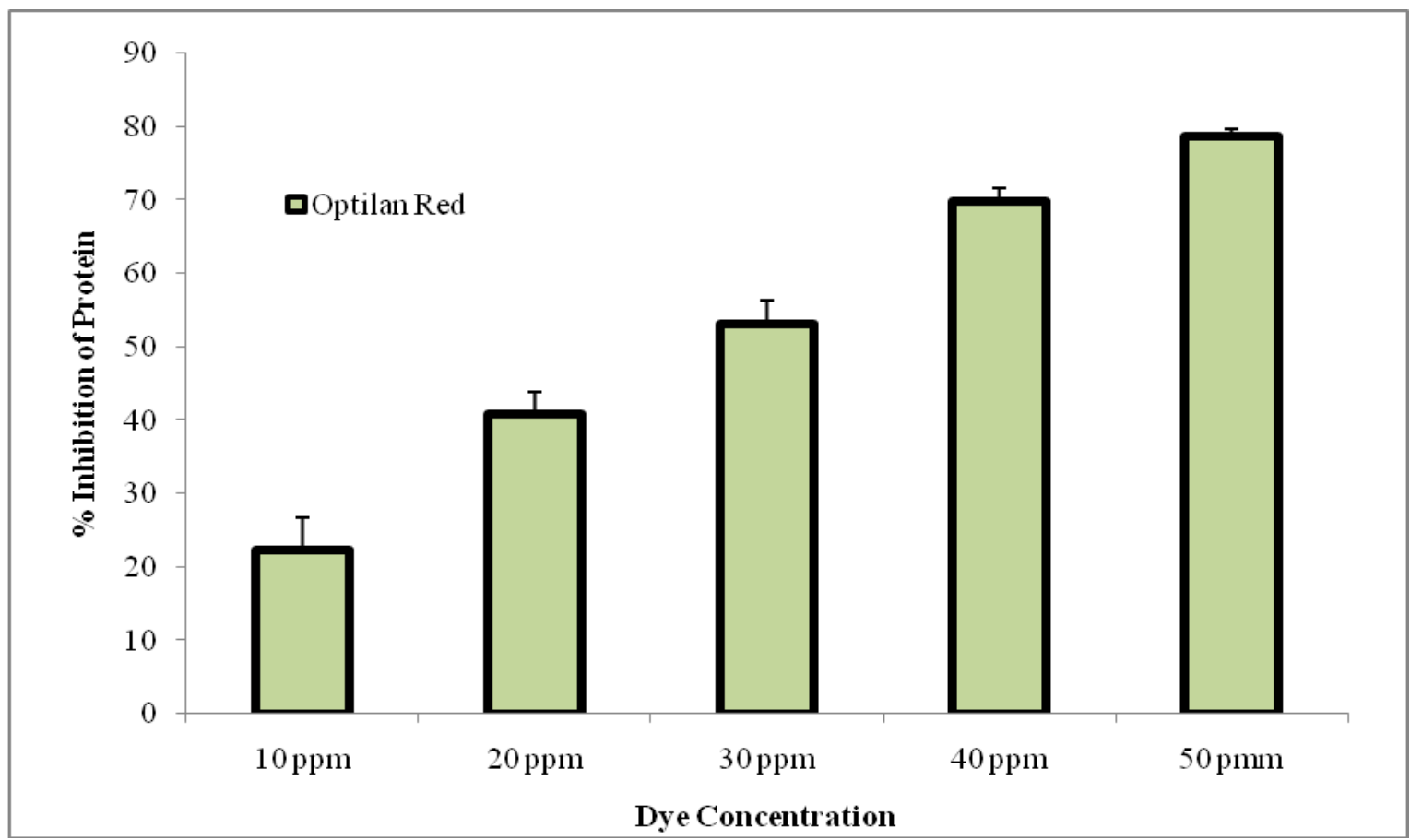

Fig.3 Effect of various concentrations of Optilan Red on the pigment content of C. vulgaris. Data are represented in mean $\pm \mathrm{SE}, \mathrm{n}=3$. The data labels represent the significant difference $(\mathrm{p}<0.05)$

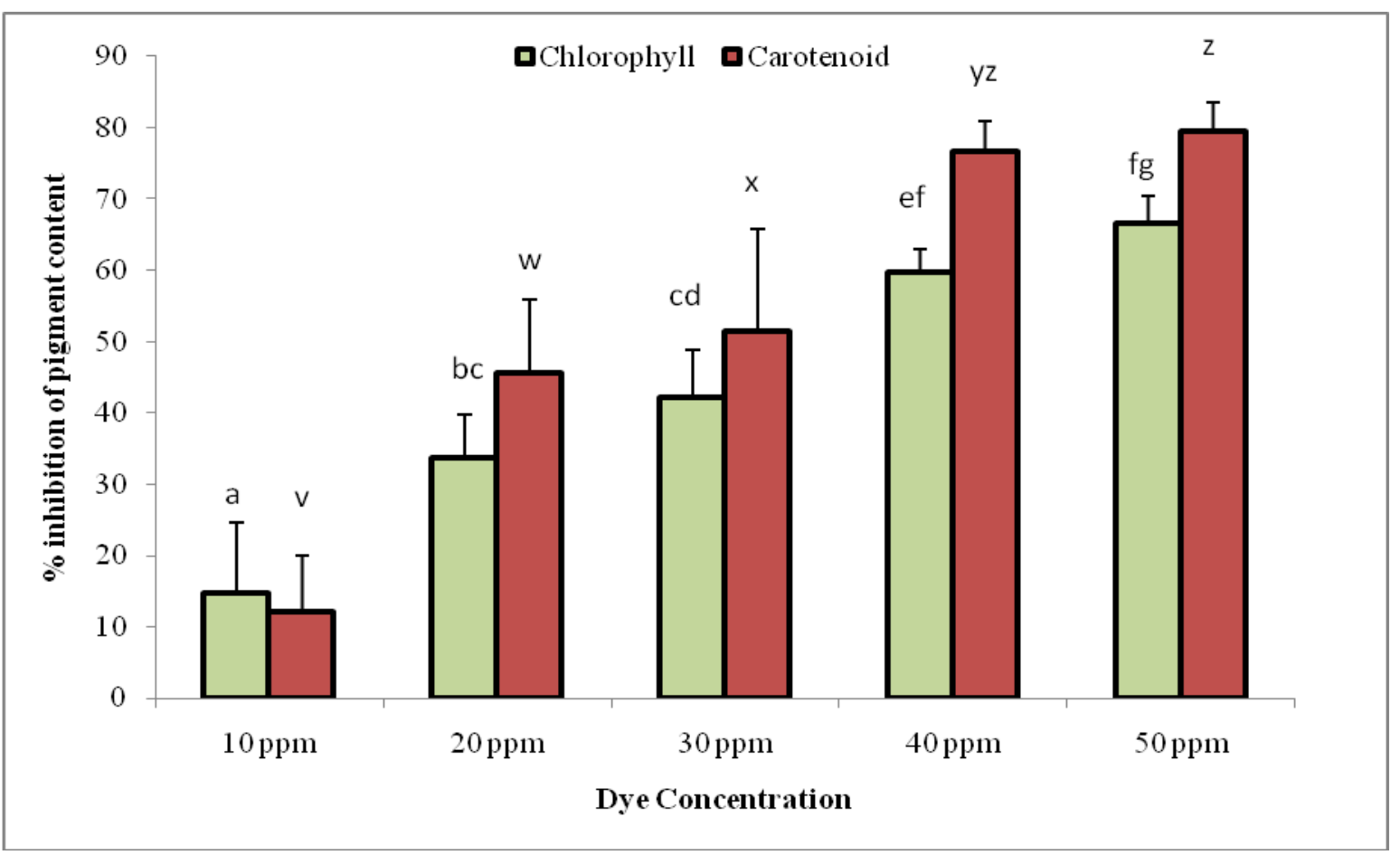


More than $50 \%$ reduction in level of both pigments was found at $50 \mathrm{ppm}$ as compared to control. For the pigment chlorophyll, maximum percentage inhibition of $66.6 \%$ was obtained in $50 \mathrm{ppm}$ concentration. Whereas for carotenoids, maximum percentage inhibition of $79.4 \%$ was found in $50 \mathrm{ppm}$ concentration. A significant $\quad(\mathrm{p}<0.05)$ difference in pigment inhibition for different treatment groups was observed (Figure 3).

\section{Effect of textile dyes on elemental composition of $C$. vulgaris}

Carbon, nitrogen, hydrogen and sulfur content were estimated from the $\mathrm{EC}_{50}$ value of the dye exposed to $C$. vulgaris cells for 96-h for both treatments and control. $\mathrm{EC}_{50}$ values for Optilan Red dye were found to be $23.16 \mathrm{ppm}$. On applying $\mathrm{t}$ test, it was noticed that the percent value of carbon and sulfur content was significantly different from control whereas hydrogen and nitrogen were not significantly different from control (Table 2).

In the present study, the growth of $C$. vulgaris was reported upto $20 \mathrm{ppm}$ after which no growth was detected. In case of protein content, there was significant reduction in level of protein was detected with increase in concentration. Shukla et al., (1992) also reported decreased in level of protein of microalgae Nostoc muscorum with toxic effect of textile dye Metomega Chrome Orange GL. Whereas pigment chlorophyll and carotenoid was also found decreased with increase in concentration. For chlorophyll, maximum percentage inhibition of $66.6 \%$ was observed and $79.4 \%$ for carotenoid was observed. Shukla et al., (1992) also reported the decreased content of pigments for both chlorophyll and carotenoid in microalgae when exposed to textile dye.

The elemental composition of $C$. vulgaris was also found significantly different as compared to control for carbon and sulphur content. The significant reduced in the content of sulfur may be due to decrease in amino acid of protein of the microalgae due to toxicity.

From the above data, it shows that Optlian Red dye is toxic to microalgae $C$. vulgaris in term of growth, protein content, pigments content and also in elemental composition. Therefore, assessment of toxicity of textile dye is of prime important in order to protect the aquatic organism as well as from the pollution of dye in aquatic environment.

\section{Acknowledgement}

The authors are thankful to Director, ICARCentral Institute of Fisheries Education for providing the necessary facilities to carry out the Ph.D. research work. S. Gita acknowledges the valuable inputs from the advisory committee members. The courtesy of Archroma, Mumbai for providing the dyes free of cost is acknowledged with thanks. This research did not receive any specific grant from funding agencies in the public, commercial, or not-for-profit sectors.

\section{References}

Allen, M.M.1968. Simple conditions for growth of unicellular blue-green algae. J. Gen. Microbiol. 51, 199 - 202.

Bafana, A., Devi, S.S and Chakarbarti, T. 2011. Azo dyes: past, present and the future. Environ. Rev.19, 350-370.

Ben, M.H., Houas, I., Montassar, F., Ghedira, K., Barillier, D., Mosrati, R and ChekirGhedira, L.2012.Alteration of in vitro and acute in vivo toxicity of textile dyeing wastewater after chemical and biological remediation. Environmental science and pollution research international. DOI 10.1007/s11356-012-0802-7.

Chamovitz, D., Sandmann, G and Hirschberg, J. 1993. Molecular and biochemical 
characterization of herbicide-resistant mutants of cyanobacteria reveals that phytoene desaturation is a ratelimiting step in carotenoid biosynthesis. Journal of Biological Chemistry. 268, 17348-17353.

Chowdhury, S and Saha, P. 2010. Sea shell powder as a new adsorbent to remove Basic Green 4 (Malachite Green) from aqueous solutions: Equilibrium, kinetic and thermodynamic studies. Chemical Engineering Journal. 164, $168-177$.

Couto, S.R. 2009. Dye removal by immobilised fungi. Biotechnology Advances. 27, 227-235.

De, P.N and Persoon, G. 1988. Micro-algae for aquaculture. In: Micro-algal Biotechnology, Cambridge University Press, Cambridge, U.K, 197-221.

Dos, S.A.B., Cervantes, F.J and Van, L.J.B. 2007. Review paper on current technologies for decolourisation of textile wastewaters: Perspectives for anaerobic biotechnology. Bioresource Technology. 98, 2369-2385.

Drumond, C.F.M., Augusto, R. de. O.G., Anastácio, F.E.R., Carvalho, C.J., Boldrin, Z.M.V and Palma, de. O.D. Textile Dyes: Dyeing Process and Environmental Impact, Eco-Friendly

Textile Dyeing and Finishing. Dr. Melih Gunay (Ed.), InTech, DOI: 10.5772/53659.

Forgacs, E., Cserháti, T and Oros, G.2004. Removal of synthetic dyes from wastewaters: a review. Environment International. 30, 953- 971.

Gita, S., Hussan, A and Choudhury, T.G. 2017a.Impact of Textile Dyes Waste on Aquatic Environments and its Treatment. Environment \& Ecology. 35, 2349-2353.

Gita, S., Shukla, S.P., Choudhury, T.G., Prakash, C and Singh, A.R. 2017b. A prototype of novel agro-waste based column bed device for removal of textile dye Optilan Red. Water Science and Technology.p.wst2017311.

Greene, J.C. and Baughman, G.L. 1996. Effects of 46 Dyes on Population Growth of Freshwater Green Alga Selenastrum capricornutum. Textile Chemist and Colorist. 28, 23-30.

Hubbe, M.A., Beck, K.R., O'Neal, W.G and Sharma, Y.C. 2012. Cellulosic substrates for removal of pollutants from aqueous systems: a review. Bioresources. 7, 2592-2687.

Ibrahim MB, Poonam N, Datel S and Roger M. 1996. Microbial decolorization of textile dye containing effluents: a review, Bioresource Technology. 58, 217-227.

Kirk, O., 2004. Encyclopedia of Chemical Technology. 5th edition, Wiley Interscience. Pp. 872.

Kratz, W.A and Myers, J. 1955. Photosynthesis and respiration of three blue-green algae. Plant Physiology. 30, 275-280.

Lowry, OH., Rosenbrough, N.J., Farr, A.L and Randal, R.J. 1951. Proteins estimation by Folin phenol method. The Journal of Biological Chemistry.193-265.

Moran, R. 1982. Formulae for determination of chlorophyllous pigments extracted with N, N-dimethyl formamide. Plant physiology. 69, 1376-1381.

Novotny, C., Dias, N., Kapanen,A., Malachova, K., Vandrovcova, M., Itavaara, M and Lima, N. 2006. Comparative use of bacterial, algal and protozoan tests to study toxicity of azo- and anthraquinone dyes. Chemosphere. 63, 1436-1442.

OECD 201.1984. OECD Guideline for Testing of Chemicals. Alga, growth inhibition test.

Ogugbue, C.J and Sawidis, T. 2011. Bioremediation and Detoxification of 
Synthetic Wastewater Containing Triarylmethane Dyes by Aeromonas hydrophila Isolated from Industrial Effluent. Biotechnology Research International; DOI 10.4061/2011/967925.

O'Neill, C., Hawkes, F.R., Hawkes, D.L., Lourenyo, N.D., Pinheiro, H.M and Delee, W. 1999. Colour in textile effluents-sources, measurement, discharge consents and simulation. A review. Journal of Chemical Technology and Biotechnology. 74,1009-1018.

Pinheiro, H.M., Touraud, E and Thomas, O. 2004. Aromatic amines from azo dye reduction: status review with emphasis on direct UV spectrophotometric detection in textile industry wastewaters. Dyes Pigments. 61, 121139.

Przystaś, W., Zabłocka, G.E and Grabińska, S.E.2012.Biological Removal of Azo and Triphenylmethane Dyes and Toxicity of Process By-Products. Water Air Soil Pollution. 223, 15811592.

Razo, F.E., Luijaten, M., Donlon, B., Lettinga, G and Field, A. 1997. Complete biodegradation of the azo dye azodisalicylate under anaerobic conditions. Environmental Science Technology. 31, 2098-2103.

Ripka, R., Deruelles, J., Waterbury, J.B., Herdman, M and Stainer, R.Y. 1979. Generic assignment, strain histories and properties of pure cultures of cyanobacteria. J. Gen. Microbiol. 111, $1-61$.

Rocha, O.P., Cesila, C.A., Christovam, E.M., Barros, S.B., de, M., Zanoni, M.V.B and de Oliveira, D.P. 2016. Ecotoxicological risk assessment of the "Acid Black 210" dye. Toxicology. http://dx.doi.org/10. 1016/j.tox.2016.04.002.

Sen, S and Demirer, G.N. 2003. Anaerobic treatment of real textile wastewater with a fluidized bed reactor. Water Research. 37, 1868-1878.

Shukla, S.P., Tiwari, A.K., Tiwari, D.N., Mishra, B.P and Gupta, G.S. 1992. Assessment of the effect of the toxicity of a textile dye on Nostoc muscorum ISU, A Diazotrophic cyanobacterium. Environmental Pollution. 84, 23-25.

Srivastava, S., Sinha, R and Roy, D. 2004. Toxicological effects of malachite green. Aquatic Toxicology. 66, 319329.

Syafalni, S., Abustan, I., Dahlan, I., Wah, C.K and Umar, G. 2012. Treatment of dye wastewater using granular activated carbon and zeolite filter. Modern Applied Science. 6, 37- 51.

Wijetunga, S., Li, X.F and Jian, C. 2010. Effect of organic load on decolourization of textile waste- water containing acid dyes in upflow anaerobic sludge blanket reactor. Journal of Hazardous Materials. 177, 792-798.

\section{How to cite this article:}

Samchetshabam Gita, S.P. Shukla, Chandra Prakash, Neelam Saharan and Geetanjali Deshmukhe. 2018. Evaluation of Toxicity of a Textile Dye (Optilan Red) towards a Green Microalga Chlorella vulgaris. Int.J.Curr.Microbiol.App.Sci. 7(08): 3346-3355. doi: https://doi.org/10.20546/ijcmas.2018.708.358 